\title{
Bystander memory CD8 T cell proliferation after anti-CD40/IL-2 treatment is independent of CD4 T cells
}

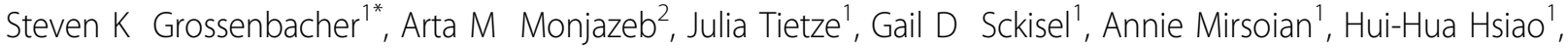 \\ Brent Koehn ${ }^{3}$, Danice Wilkins ${ }^{1}$, Bruce R Blazer ${ }^{3}$, William J Murphy ${ }^{1}$ \\ From Society for Immunotherapy of Cancer 28th Annual Meeting \\ National Harbor, MD, USA. 8-10 November 2013
}

Systemic cancer immunotherapy combining agonistic antiCD40 and interleukin 2 results in synergistic anti-tumor effects with marked antigen independent expansion of bystander memory CD8 $\mathrm{T}$ cells displaying anti-tumor abilities. Our lab has previously shown that this expansion coincides with a loss of peripheral CD4 $\mathrm{T}$ cells due to activation induced cell death. While much research to date has focused on the effects of CD4 T cells on antigenspecific CD8 $\mathrm{T}$ cell expansion, little is known regarding the role of $\mathrm{CD} 4 \mathrm{~T}$ cells in bystander $\mathrm{CD} 8 \mathrm{~T}$ cell expansion. Utilizing models of CD4 knockout mice as well as CD4 depleting antibodies we observed a significant expansion of memory CD8 $\mathrm{T}$ cells displaying a CD25-NKG2D+ bystander phenotype following immunotherapy, similar to non-depleted mice. Interestingly, the expanded bystander memory population was enriched from cells of the effector memory phenotype and up regulated Tim- 3 and PD- 1 in the absence of CD4 T cells. However, they also displayed comparable cytokine production and lytic ability suggesting no functional impairment or exhaustion. While Tim-3 and PD-1 expression have previously been linked to exhaustion, the phenotype described here is consistent with their other known role as acute activation markers on effector/effector memory $\mathrm{T}$ cells. These results suggest that $\mathrm{CD} 4 \mathrm{~T}$ cells may not be necessary for the expansion and activation of antigen-nonspecific bystander memory CD8 $\mathrm{T}$ cells under conditions of strong immune stimulation yet may play a role in regulating the conversion of these bystander cells from a central to effector memory phenotype in secondary lymphoid organs.

'Dermatology, University of Califonia, Davis, Sacramento, CA, USA

Full list of author information is available at the end of the article

\section{Authors' details}

'Dermatology, University of Califonia, Davis, Sacramento, CA, USA. ${ }^{2}$ Radiation Oncology, University of Califonia, Davis, Sacramento, CA, USA. ${ }^{3}$ Pediatrics,

University of Minnesota, Minneapolis, MN, USA.

Published: 7 November 2013

doi:10.1186/2051-1426-1-S1-P100

Cite this article as: Grossenbacher et al:: Bystander memory CD8 T cell proliferation after anti-CD40/LL-2 treatment is independent of CD4 T cells. Journal for ImmunoTherapy of Cancer 2013 1(Suppl 1):P100.

Submit your next manuscript to BioMed Central and take full advantage of:

- Convenient online submission

- Thorough peer review

- No space constraints or color figure charges

- Immediate publication on acceptance

- Inclusion in PubMed, CAS, Scopus and Google Scholar

- Research which is freely available for redistribution 